\title{
Proportional Banking Regulation System in Russia Based on the Concept of Basel III
}

\author{
Natalya N. Mokeeva*, Larisa I. Yuzvovich, Natalya Y. Isakova, \\ Valeriya B. Rodicheva
}

Ural State University of Economics, Yekaterinburg 620144, Russia

*Corresponding author. E-mail: natmokeeva@yandex.ru

\begin{abstract}
International approaches to a stricter definition of capital, increasing the minimum requirements for its value, and introducing new evaluation criteria will make it easier for banks to survive a period of economic instability. Experts believe that these innovations will make unstable participants leave the market and expand opportunities for those banks that are more stable and able to cover risks in critical situations. Compliance with the new regulations will require banks to raise significant amounts of additional capital. An alternative source of such capital may become the profit of banks, therefore shareholders will have to review the dividend policy in favor of improving the quality of funding.
\end{abstract}

Keywords: Basel III, banking system, financial leverage, proportional banking regulation, bank capital, liquidity

\section{INTRODUCTION}

Discussion aspects and pertinent issues of this topic influenced the purpose and objectives of the research.

National regulators and regulation entities have mixed views on the tightening of regulations in the concept of Basel III. Some countries, such as the United States, Great Britain, and Switzerland, have national standards that are much stricter than the requirements of the Basel Committee. The performance indicators of individual banks in the United States, Canada, Belgium, the Netherlands, Luxembourg, the United Kingdom, Switzerland and the Scandinavian countries have also been meeting the new requirements for several years. The primary impact of Basel III has been on countries of the Euro Zone, which have some peculiarities in functioning of their banking systems, and criticism focused primarily on the fact that the new requirements will lead to banks being forced to significantly reduce lending due to non-compliance with the capital requirement. In these segments, there are small financial and credit structures that are more focused on servicing the segment of small and medium-sized businesses, as well as individuals. They have very limited access to the corporate bond market and are more dependent on government loans. Russian banks started switching to Basel III in December 2013, when documents were published that defined a new procedure for calculating capital and its adequacy ratios. Then, certain elements were gradually introduced, considering the features of 2014, which significantly slowed down the economic situation in the country. Since 2015 , the specifics of calculating the short-term liquidity ratio for systemically important banks and capital buffers for all credit institutions have been outlined. In 2017, implementation of the system of proportional regulation of the banking sector in Russia began.

\section{ANALYSIS OF RECENT ACHIEVEMENTS AND PUBLICATIONS}

The theoretical and methodological basis of this topic is research in the field of economics in the conceptual and modern interpretation of the basics of banking regulation of bank capital and bank liquidity, monographs, scientific articles on the basic aspects of implementation of Basel III in different countries, including Russia.

The conceptual aspects of the study are covered in the works of a large circle of specialists; and from them it is worth highlighting the research of such economists as: Rosenberg J., Rose P., Sinki J., Harris L. and others.

The fundamental works of such economists as Bogomolov S. M., Dzhagityan E. P., Leontiev A. B., Lobanov A. A., Ovchinnikova N. E., Pozdyshev V. A., Savinova V. A., Fedotova T. V., etc. are devoted to the study of introduction of Basel III in Russia and the study of basics of proportional banking regulation in modern economic conditions of Russia.

The practical part of the information base of the study was made up of legal and regulatory documents adopted by the Basel Committee on Banking Supervision and the Bank of Russia on the introduction of new banking regulatory frameworks that change the concept of calculating the Bank's own funds, its individual elements, and the introduction of new financial ratios (financial leverage and liquidity). 


\section{FORMULATION OF THE OBJECTIVES AND TASKS}

The purpose of the study is to explore the main conceptual foundations of Basel III and specifics of their implementation, considering implementation of the system of proportional regulation in Russia.

This purpose of the article requires to solve specific objectives of the study:

- to systematize the main parameters of Basel III, considering the analysis of innovations in the assessment and calculation of capital, the use of new coefficients; to identify advantages and disadvantages of new approaches; - to analyze the features of Basel III introduction considering the system of proportional banking regulation in Russia;

- based on the assessment of qualitative characteristics of the Russian banking sector, to identify the degree of impact of Basel III on the country's banking system.

\section{MAIN RESEARCH MATERIAL}

The international community, led by the Basel Committee on Banking Supervision, has been implementing measures over the past years to improve the banking system's stability. The main measures are related to the introduction of new requirements for increasing liquid reserves and improving the quality of capital. The next tranche of amendments should minimize the risks that led to the global economic crisis in 2008. The financial condition of banks should be strengthened in parallel with an adequate risk management policy.

Thus, the Basel Committee on Banking Supervision developed and approved (2010-2011) a package of reforms in the field of banking regulation - Basel III. It should be noted that the task of the new Basel is not to cancel, but to improve the already adopted documents. Therefore, after the adoption of Basel III all the requirements that were introduced earlier in the capital part remain in force. This also applies to the issues of supervision and market discipline. At present, the representatives of central banks and financial regulatory authorities from 28 countries (including Russia) are parties to the Basel agreements and several countries and organizations work in the status of observers.

The introduction of Basel III was carried out in III stages: [1]

I stage: 2013-2014 the reform of requirements for the structure of assets and capital of banks. In parallel, central banks should tighten the requirements for the share of equity in the structure of general regulatory capital.

II stage: 2014-2018 improving the quality of capital by eliminating individual components.

III stage: 2016-2019 introduction of a capital conservation buffer and an anti-cyclical buffer.

Because of the reform, a new term, included in the practice of banking regulation was introduced, namely: 'regulatory capital', which is the minimum amount of a bank's own funds established by the Central Bank of the country, which must be constantly maintained to minimize credit, market and operational risks. The authors present the constituent elements of regulatory capital in Table 1. Regulatory capital requirements are set by the country's regulatory documents.

Table 1 Regulatory capital structure [1]

\begin{tabular}{|c|c|c|}
\hline \multicolumn{3}{|c|}{ Regulatory capital (Tier $1+$ Tier 2 ) $\min 8 \%$} \\
\hline $\begin{array}{l}\text { Capital of Ti } \\
\text { of losses du }\end{array}$ & $\begin{array}{l}\text { (Tier } 1) \text {-coverage } \\
\text { current operations } \\
\text { in } 6 \%\end{array}$ & $\begin{array}{l}\text { Capital of Tier } 2 \\
\text { (Tier } 2 \text { ) - } \\
\text { coverage of }\end{array}$ \\
\hline $\begin{array}{l}\text { Base capital } \\
\text { (CET1) min } \\
4,5 \%\end{array}$ & $\begin{array}{l}\text { Additional capital } \\
\text { (AT1) min } 1,5 \%\end{array}$ & $\begin{array}{l}\text { losses during } \\
\text { business } \\
\text { termination } \min \\
2 \%\end{array}$ \\
\hline
\end{tabular}

Thus, the base capital includes assets of the highest quality that cover losses immediately when they occur. Additional capital includes other assets necessary to cover losses on an ongoing basis. Some debt instruments can only be included in this calculation (for example, perpetual financial instruments on condition that the Bank's claims for them can be converted into shares under certain circumstances). The criteria for including assets in Tier 2 capital are less strict, which allows fixed-term instruments (i.e. instruments with a set maturity date) to be included in this calculation. One of the main innovations of Basel III was a significant increase in the requirements for Tier 1 capital structure, which is recommended to include only shares and retained earnings. The additional paid-in capital may contain perpetual debt instruments, while the additional capital may only contain fixed-term instruments. The fixed capital must triple the additional capital. Thus, the capital will be used not only to insure market risk, but also to minimize credit and operational risks, respectively. The very scheme for calculating capital adequacy ratios (1) does not change, but the constituent elements undergo significant changes:

$$
=\frac{\begin{array}{c}
\text { Capital adequacy ratios } \\
\text { Regulatory capital }
\end{array}}{\text { Risk-weighted assets }}
$$

The specifics of calculating regulatory capital are presented in Table 1. Meanwhile, for the purposes of banking supervision, the bank's own fund sources also include other assets that are complex financial instruments. These include subordinated loans (deposits, loans, including bond loans). Attribution of these instruments to the sources of the bank's own funds is primarily since the holder of a specified financial instrument, by purchasing it, guarantees the bank its participation in taking on part of the bank's possible losses, on the terms and in the manner provided for by these financial instruments.

The introduction of two new buffers has the following characteristics.

The capital conservation buffer is an indicator that helps banks maintain capital levels during significant economic downturns and adjust the level of dividend payments during certain periods. If banks are to operate as close as possible 
to the threshold value, then during crisis, capital adequacy will be violated. This indicator is introduced to avoid such situations, thereby the share capital can be reduced, but only to the extent of the buffer. The source of the buffer is the share capital after all necessary deductions.

Countercyclical capital buffer is capital formation exceeding the regulatory minimum. Thus, the additional reserve capital will be formed on basis of expected losses, rather than those that banks have already incurred. During periods of rapid credit growth, banking supervisors can use it as a tool for macroprudential regulation.

Basel III also introduced 3 new coefficients:

1. Leverage ratio - the ratio of the bank's borrowed funds to its own funds at the level of $3 \%$. This coefficient has become a new indicator that complements the calculation of risk-based capital indicators.

2. Short-term liquidity indicator - reflects the amount of unencumbered highly liquid assets available to the bank. The indicator value must be more than $100 \%$, i.e. the stock of liquid assets must be at least equal to the probable net cash outflow. The calculation of the indicator for monitoring purposes was introduced on January 1, 2013; it entered into force as a regulatory requirement on January 1, 2015.

3. Net stable funding indicator on a regular basis - assesses the amount of long-term stable funding sources depending on the level of liquidity of the funded assets and probability of the need to search for sources of liquidity because of execution of off-balance sheet obligations. It entered into force as a regulatory requirement on January 1, 2018.

Modern economists believe that the main advantages of Basel III are as follows:

- the result of fulfillment or non-fulfillment by the bank of specific indicators and calculation of the final result characterizes the degree of reliability and creditworthiness of the bank as a whole;

- the added new criteria make it possible to form reasoned conclusions on the financial position of banks;

- the banking system and the economy are becoming more resilient to crises.

The disadvantages of Basel III are as follows:

- new requirements for subordinated debt increase its cost for banks;

- banks resort to raising rates, which leads to a slowdown in economic growth;

- reduced profitability of the banking business pushes banks to more risky operations.

Basel III is implemented in Russia in stages, considering adjustments made by the current economic situation. First, the Bank of Russia's Regulation No. 395-П 'On the Methodology for Determining the Amount of Equity (Capital) of Credit Institutions ('Basel III')' was adopted on 28.12.2012. At the current stage in Russia, Basel III is being implemented under the second document - the Bank of Russia's Regulation No. 646-П 'On the Methodology for Determining the Equity (Capital) of Credit Institutions ('Basel III')' dated 04.07.2018. The Bank of Russia has stepped up banking supervision of credit institutions in terms of studying and analyzing the sources of their own funds for their compliance with the requirements of the Bank of Russia's regulations developed on basis of Basel
III. Such increased attention on the part of the regulator is due primarily to the fact that its financial stability, the occurrence of insolvency (bankruptcy) risk and, as a consequence, the risk of property losses of its depositors depend on the specific composition and quality of the sources of the bank's own funds. In 2017, the Bank of Russia introduced a system of proportional regulation of the banking sector in the Russian Federation. Federal Law No. 92-Ф3 'On Amending Certain Legislative Acts of the Russian Federation' dated 01.05.2017 defined these procedures and entered into force on 01.06.2017. The main goal of the law is to create a regulatory balance for banks with different volumes and nature of operations [2]. The proportional regulation system divided banking licenses into universal and basic and established various requirements for a minimum amount of authorized capital. From June 1, 2017, all banks were recognized as banks with a universal license regardless of the amount of capital - the status was acquired automatically [2]. The system of proportional regulation touched on many aspects in the field of banking business; the authors considered it advisable to dwell only on issues related to capital as part of the study (Table 2).

Table 2 Features of capital regulation for banks with basic and universal licenses [2,3]

\begin{tabular}{|c|c|}
\hline Basic license & Universal license \\
\hline \multicolumn{2}{|c|}{ Minimum authorized capital at the time of creation } \\
\hline $\begin{array}{l}\text { Minimum } 300 \\
\text { million rubles }\end{array}$ & Minimum 1 billion rubles \\
\hline \multicolumn{2}{|c|}{ Capital adequacy ratios } \\
\hline $\begin{array}{l}\text { 1. capital adequacy } \\
\text { ratio of a bank (H1.0) } \\
\text { min }-8 \% \text {; } \\
\text { 2. basic capital } \\
\text { adequacy ratio of a } \\
\text { bank (H1.2) min - } \\
6 \% \text {; }\end{array}$ & $\begin{array}{l}\text { 1. capital adequacy ratio of a } \\
\text { bank (H1.0) min }-8 \% \text {; } \\
\text { 2. basic capital adequacy ratio } \\
\text { of a bank (H1.1) min }-4,5 \% \text {; } \\
\text { 3. basic capital adequacy ratio } \\
\text { of a bank (H1.2) min }-6 \% \text {; } \\
\text { 4. leverage ratio (H1.4) min - } \\
3 \% \text {. }\end{array}$ \\
\hline
\end{tabular}

These requirements, as we see, comply with the concept of Basel III. The mechanism for calculating capital adequacy ratios is demonstrated by formula 1 , and specifics by type are associated with the inclusion of the corresponding type of capital in the calculation. As stipulated by international banking standards, a prerequisite for including a source of funds in calculating the capital of a Russian bank is its ability to cover losses arising from activities of such a bank. In this regard, the main sources of the bank's own funds are its authorized capital, the reserve fund and retained earnings.

The financial leverage ratio has become a new indicator for banks (2), it is very relevant in a cyclical economy.

$$
=\frac{\begin{array}{c}
\text { Financial leverage ratio } \\
\text { Fixed capital }
\end{array}}{\left(\begin{array}{c}
\text { Assets and off }- \text { balance sheet instruments } \\
\text { are not risk-weighted })
\end{array}\right.}
$$


The components of fixed capital were considered by the authors above. The calculation of the denominator of Formula 2 includes the carrying amount of assets less reserves, contingent credit commitments, credit risk on futures transactions and derivative financial instruments. In accordance with Bank of Russia's regulations, the requirements for this regulation were introduced in stages: data collection from August 1, 2013; mandatory public disclosure from January 1, 2015; mandatory standard from 2018. Undoubtedly, introduction of the financial leverage standard is reflected on those banks that have significant off-balance sheet positions and carry out a significant amount of investment operations.

Thus, in general, the introduction of Basel III capital requirements has a positive effect on the creditworthiness of Russian banks. There is no increase in the amount of capital, but its quality improves due to replacement of the old subordinated debt, but at the same time the risks for the holders of subordinated debt increase.

It should be noted that systemically important banks are given special status in the banking sector of Russia; they are fully covered by all requirements for banks with a universal license, plus ratios and capital surcharges for systemically important credit organizations. The minimum allowable numerical value of the premium for system significance is set at $1 \%$ of risk-weighted assets.

The regulation of liquidity indicators for Basel III is determined by individual documents of the Bank of Russia: Regulation of the Bank of Russia No. 510-П 'On the Procedure for Calculating the Short-Term Liquidity Ratio (" Basel III ") by Systemically Important Credit Institutions' dated 03.12.2015 and Regulation No. 596-П of the Bank of Russia 'On the Procedure for Calculating the Structural Liquidity Ratio (Net Stable Funding Ratio) by Systemically Significant Credit Institutions (Basel III)' dated 26.07.2017.

Let us consider the features of the calculations of these ratios.

The short-term liquidity ratio (STLR) regulates (limits) the risk of liquidity loss, which is understood as the ability of a banking group (credit organization) to ensure timely, full fulfillment of its monetary and other obligations and the ability to continue its activities in conditions of instability caused by external and (or) internal factors in relation to the banking group (credit institution), within the next 30 calendar days from the date of STLR calculation (3).

$$
\begin{aligned}
& \text { Short }- \text { term liguidity ratio }= \\
& \text { Het out flow of liquidity in } 30 \text { days }
\end{aligned}
$$$$
=
$$

In the Russian Federation, this ratio has received the parameter H26 (for banking group) and H27 (for credit institution). It entered into force as a regulatory requirement on January 1, 2015. The minimum allowable numerical value of the ratios $\mathrm{H} 26$ and $\mathrm{H} 27$ was established in the amount of: 70\% from January 1, 2016; 80\% from January 1, 2017; $90 \%$ from January 1, 2018; 100\% from January 1, 2019.
The net stable funding ratio (NSFR) regulates (limits) the liquidity risk of a systemically important credit institution, banking group, due to the structure of assets (claims) and liabilities (liabilities), taking into account the terms, amounts and types of assets (claims) and liabilities, as well as other factors characterizing the liquidity of assets (claims) and the stability of liabilities (4).

$$
\begin{gathered}
\text { Net stable funding ratio }= \\
\frac{\text { Stable funding sources owned by the bank }}{\text { Necessary amount of stable funding }}
\end{gathered}
$$

In the Russian Federation, this ratio obtained parameter $\mathrm{H} 28$ (on a consolidated basis for the parent credit institution of the banking group, which is a systemically important credit institution) and $\mathrm{H} 29$ (on an individual basis for the systemically significant credit organization that is not the parent credit organization of the banking group). It entered into force as a regulatory requirement on January 1, 2018. The minimum allowable numerical value of the standards $\mathrm{H} 28$ and $\mathrm{H} 29$ is set at $100 \%$.

Obviously, the measures introduced by the regulator have affected the country's banking system (Table 3).

Table 3 Selected indicators of the banking system of Russia [5]

\begin{tabular}{|l|c|c|c|}
\hline \multicolumn{1}{|c|}{ Index } & 2017 & 2018 & 2019 \\
\hline $\begin{array}{l}\text { 1. Existing credit } \\
\text { organizations, } \\
\text { units, of which: }\end{array}$ & 561 & 484 & 442 \\
\hline banks: & 517 & 440 & 402 \\
\hline $\begin{array}{l}\text { - with universal } \\
\text { license }\end{array}$ & - & 291 & 266 \\
\hline $\begin{array}{l}\text { - with basic } \\
\text { license }\end{array}$ & - & 149 & 136 \\
\hline $\begin{array}{l}\text { non-bank credit } \\
\text { organizations }\end{array}$ & 44 & 44 & 40 \\
\hline $\begin{array}{l}\text { 2. Assets / } \\
\text { liabilities of the } \\
\text { balance of the } \\
\text { banking system of } \\
\text { the Russian }\end{array}$ & 85191.8 & 94083.7 & 96581.1 \\
$\begin{array}{l}\text { Federation, billion } \\
\text { rubles }\end{array}$ & 2667.5 & 2695.8 & 2875.3 \\
\hline $\begin{array}{l}\text { 3. Own funds } \\
\text { (capital) of the } \\
\text { banking system, } \\
\text { billion rubles }\end{array}$ & 9397.3 & 10269.3 & 10981.1 \\
\hline $\begin{array}{l}\text { 4. Authorized } \\
\text { capital, billion } \\
\text { rubles }\end{array}$ & 789.7 & 1344.8 & 2036.8 \\
\hline $\begin{array}{l}\text { 5. Volume of } \\
\text { profit / loss, } \\
\text { billion rubles }\end{array}$ & $21 / 140$ & $384 / 100$ & $373 / 69$ \\
\hline $\begin{array}{l}\text { 6. Profitable } \\
\text { /unprofitable } \\
\text { credit } \\
\text { organizations }\end{array}$ & & & \\
\hline
\end{tabular}


In general, the presented analytical data, on the one hand, shows that the number of banking institutions is still decreasing, on the other hand, confirm feasibility of the reforms that the Bank of Russia has been carrying out over the past few years. A reduction in the number of banks is not always a sign of liquidation; the issue of mergers and acquisitions remains relevant in the system. The increase in the volume of currency balance of the banking system is just part of its qualitative characteristics, as well as the growing authorized capital, profit volume and a reduction in the number of unprofitable credit organizations.

The advantages of the introduced system of proportional regulation include:

- banking regulation is changing in accordance with international standards established by the Basel Committee [6];

- minimum regulatory measures for banks with a basic license;

- banks with a universal license have competitive advantages in the financial market and in terms of banking operations;

- forming niches for small banks for working with regional enterprises in the status of small and medium-sized businesses.

The disadvantages of the introduced system of proportional regulation include:

- maximum regulatory measures for banks with a universal license;

- decrease in the competitiveness of banks with a basic license in terms of individual banking operations;

- rise in price of banking services.

In 2017, the methodology for analyzing sensitivity to risk of liquidity loss was improved considering the recommendations proposed by the Basel Committee on Banking Supervision. Thus, the methodology is supplemented with higher detail of the types of outflows, as well as balance sheet items that can be used to cover them. Which will certainly have an impact on the process of managing liquidity risk [7].

Thus, starting in 2018, a mechanism for the formation of a multi-level banking system has been launched in the country's banking sector. что банковский бизнес будет Obviously, it is too early to draw detailed conclusions on what subsequent results these innovations will lead to, but at this stage it can be stated that the banking business will be more conscientious in addressing financial management issues, which will favorably contribute to further improvement of the system's quality, provide protection to depositors and increase the level of confidence in banking operations and transactions.

\section{CONCLUSION}

Thus, implementation of the requirements of Basel III not only means strengthening regulation of banks, but also provides for a significant increase in capital requirements. Undoubtedly, not all banks have sources for such funding. To increase Tier 1 basic capital adequacy ratio, banks that are not able to increase fixed capital will be forced to reduce their active operations, which will certainly affect profit margins. Moreover, in addition to reducing lending volumes, this will also affect high-risk, but profitable operations with securities. Tighter requirements may lead to a change in the business models of banks.

In accordance with Basel III, the capital buffer must be maintained constantly and the bank must replenish the stock when it is reduced, either by reducing the distribution of profits or by attracting new capital. A few banks received additional recapitalization opportunities through bond issue. Moreover, a feature of this buffer is compliance with the required minimum level. A countercyclical buffer can form when growth is observed in the economy. Thus, in Russia now it equals 0 (since 2016).

Undoubtedly, Russian banks are interested in creating these buffers independently without control by the supervisor, as several risks are not covered by the capital adequacy ratio, but it all depends on the current market situation and the bank's capabilities.

The new liquidity standards have so far only affected systemically important banks, since Basel III interprets them just for internationally active banks. Therefore, the short-term liquidity ratio has been developed for countries where there is no shortage of highly liquid assets, where banks can acquire government debt in the required volume and thereby fulfill this standard. Russia also belongs to such countries and therefore the implementation of the standard was limited to a group of 11 systemically important banks, these banks also got the opportunity to include limits on irrevocable credit lines (a new refinancing tool) in the composition of highly liquid assets.

It can be concluded that Basel standards partially solve their main goals: firstly, to reduce the cost of customer funds to address banking sector issues, and secondly, to make the assessment of banking risks more appropriate to the conditions of economic realities.

\section{REFERENCES}

[1] Group of Governors and Heads of Supervision announces higher global minimum capital standards. [Electronic resource]. - Available at: https://www.bis.org/press/p100912.pdf

[2] On Amendments to Certain Legislative Acts of the Russian Federation: Federal Law No. 92-Ф3 from 01.05.2017. The System ConsultantPlus. - [Electronic resource]. - Available at: http://www.consultant.ru/document/cons_doc_LAW_2 16074/

[3] On Mandatory Standards and Allowances for Capital Adequacy Ratios of Banks with a Universal License: Bank of Russia's Instruction No. 199-И dated 29.11.2019. The System ConsultantPlus. - [Electronic resource]. - Available at: http://www.consultant.ru/document/cons_doc_LAW_3 42089/ 
[6] Pozdyshev V. A. Bank Regulation in 2016-2017: Main Changes and Development Prospects / / Money and Credit. 2017 No. 1. p. 9.

(183-И dated 06.12.2017. The System ConsultantPlus. - [Electronic resource]. - Available at:

http://www.consultant.ru/document/cons_doc_LAW_2 92457/

[5] Central Bank of the Russian Federation: official website. [Electronic resource]. - Available at: http://www.cbr.ru/analytics/bnksyst/
[7] N.N. Mokeeva, T.V. Bakunova, V.E. Frais, Modern Paradigm of Commercial Bank Funding: SocioEconomic Aspects. Proceedings of the 2nd International Conference on Education Science and Social Development (ESSD 2019). 2019 volume 298. P. 635640. DOI: https://doi.org/10.2991/essd-19.2019.138. 